Review article

\title{
Self-awareness and its evaluation in patients after acquired brain injury
}

\author{
Mária Krivošíková ${ }^{1,2}$ *, Yvona Angerová ${ }^{1}$ \\ ${ }^{1}$ Charles University, First Faculty of Medicine, Department of Rehabilitation Medicine, Prague, Czech Republic \\ ${ }^{2}$ Charles University; Second Faculty of Medicine, Prague, Czech Republic
}

\section{Abstract}

Introduction: Self-awareness deficit is a complex cognitive-behavioural disorder that is typical of patients after acquired brain injury. Deficiency of self-awareness in these patients causes reduced motivation for rehabilitation or unrealistic expectations. It leads to poorer results in therapy and problems in engaging in activities in the wider community and in employment.

Aim: The aim of this review study is to describe the definitions and theoretical models of self-awareness and to summarize the conclusions of research on how to assess self-awareness in adult patients after acquired brain injury in the last 15 years.

Methods: Review with elements of systematization using PRISMA methodology. The search was performed in bibliographic and multidisciplinary electronic databases (Web of Science, CINAHL, MEDLINE, EBSCO, ScienceDirect, Scopus). The work includes studies published from 2005 to 2020 inclusive.

Results: A total of 544 sources were found. The final research included 14 studies that fall into one of three categories: definition of selfawareness, self-awareness models, and self-awareness assessment.

Conclusions: The research shows that self-awareness is a complex concept that is part of metacognition. Its definition is inconsistent. Most often, self-awareness is conceptualized as the ability to objectively perceive and assess one's own situation while maintaining a certain subjectivity in understanding its importance to a person. Only two of the sought-after objective self-awareness assessments assess all its levels.
\end{abstract}

Keywords: Acquired brain injury; Anosognosia; Self-awareness evaluation; Self-awareness impairment

\section{Introduction}

Acquired brain injury is a serious health complication worldwide, according to epidemiological studies (Tiar and Dumas, 2015). Their incidence is growing over time and it is expected to remain one of the most common causes of death and permanent disability in the future (Powell, 2010; WHO, 2013). In the Czech Republic, about 80,000 people are affected by brain damage each year, of which 48,000 cases are strokes (Janečková, 2010; ÚZIS, 2016). Classifications of acquired brain injury (ABI) are different, usually divided according to aetiology into: traumatic brain injury (TBI), stroke (Cerebrovascular accident - CVA), brain cancer and other types of acquired brain injury (infection, hypoxia) (BIAA, 2017; Powell, 2010).

The physical, cognitive, and behavioural consequences of acquired brain injury significantly affect the life of the affected individual. The effects of brain damage on functioning in everyday life are subsequently manifested in relationships with the environment. Although acquired brain lesions are quite diverse, possible cognitive impairments are paradoxically similar for different types of lesions (Šplíchal, 2017). At the same time, it is characteristic of brain damage that some functions may be impaired, and others may remain undamaged.

In connection with acquired brain injury, many authors consider a lack of self-awareness and a reduced ability to self-assess to be a serious problem affecting everyday life (Bloomfield et al., 2016; Reich et al., 2015; Robertson and Schmitter-Edgecombe, 2015; Toglia and Kirk, 2000). According to Powell (2010), affective and behavioural problems in patients with brain damage can be caused by a lack of self-awareness or its misdiagnosis in the early stages of the disease. Lack of self-awareness can then be the background to these difficulties. Self-awareness is the ability of a person to realize his or her position in the world and contributes significantly to the healing process and to the better involvement of patients with brain damage in everyday life (Rigon et al., 2017). It is the ability of an individual to perceive himself/herself from a distance, to assess his/her behaviour, to evaluate it and to adapt to the situation. It also includes the ability of a person to understand that he/she has a problem and to solve it. Lack of self-awareness occurs very often in most patients at the onset of the disease, and usually improves over time (Klonoff, 2010). Patients with self-awareness impairment are less successful in

\footnotetext{
* Corresponding author: Mária Krivošíková, Charles University, First Faculty of Medicine, Department of Rehabilitation Medicine, Albertov 7, 12800 Prague 2; e-mail: maria.krivosikova@lf1.cuni.cz http://doi.org/10.32725/kont.2021.027 
rehabilitation programs and are less able to use compensatory strategies. Very often they make unrealistic plans and embark on activities for which they are not capable. Self-awareness reduces the effectiveness of therapy, has a negative impact on activities of daily living (ADL) and causes a person's inability to engage in work activities or more complex activities within their wider environment (Al Banna et al., 2016; Richardson et al., 2014; 2015; Toglia and Kirk, 2000).

The aim of this review study is to describe the definitions and theoretical models of self-awareness and to summarize the conclusions of research on how to assess self-awareness in adult patients after acquired brain injury in the last 15 years.

\section{Materials and methods}

Research with elements of systematization using the PRISMA methodology was chosen for the selection of suitable studies and subsequent data acquisition.

The research was carried out in September 2020. The discovery service of Charles University UKAŽ was used to search for professional studies, which searches for scientific information sources in bibliographic and multidisciplinary databases MEDLINE complete, EBSCO (Academic Search Ultimate), Web of Science (Science Citation Index), ScienceDirect, Scopus,
SPORTDiscus, SpringerLink and Journal @ Ovid. In addition to this service, the following databases were also used: ProQuest Central, CINAHL and PUBMED. Only studies that met the selection criteria and that were available in full were included in the research.

Criteria for including the study in the analysis: English sources, professional periodicals published in 2005-2020, adult population, neurological diseases.

The information search strategy combined different terms, their synonyms, and Boolean operators.

Based on a keyword search, a total of 544 articles were found, which were further classified according to the PRISMA scheme (Fig. 1).

\section{Table 1. Search strategy: keywords and phrases}

\begin{tabular}{ll} 
Main keywords & Synonyms and phrases \\
\hline Acquired brain injury & $\begin{array}{l}\text { ABI AND/OR Stroke AND/OR CVA } \\
\text { AND/OR Cerebrovascular accident }\end{array}$ \\
& $\begin{array}{l}\text { Self-awareness AND/OR Unawareness } \\
\text { AND/OR Anosognosia AND/OR Self- } \\
\text { Awareness }\end{array}$ \\
regulation AND/OR Self-evaluation \\
Measurement & $\begin{array}{l}\text { Evaluation AND/OR Scale } \\
\text { AND/OR Questionnaire AND/OR Tool }\end{array}$ \\
\hline
\end{tabular}

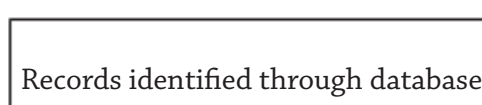
search according to set criteria

$$
(n=544)
$$

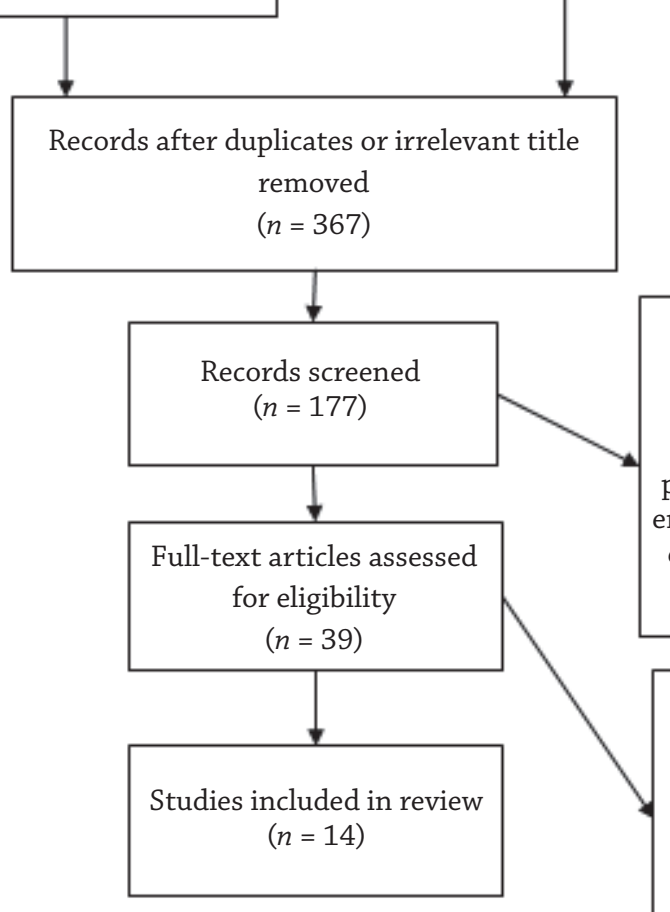

Records excluded: case studies, records from proceedings, pediatric population, psychiatric population, self-reflection in emotional intelligence studies duplicates in author's name $(n=138)$

Full-text articles excluded with reasons:

full-text unavailable in English

failure to meet all set criteria $(n=25)$

Fig. 1. PRISMA flow diagram for literature search 


\section{Results and discussion}

\section{Definition of self-awareness and its level}

There is no consensus on the exact definition of self-awareness, however it is assumed that it is a multidimensional concept. It is a deficit with a wide range of different forms and degrees.

Self-awareness requires knowledge of our strengths and weaknesses and of the various strategies we use in everyday life to evaluate various situations. According to Sherer and Fleming (2014), self-awareness involves evaluating and understanding various aspects of oneself, including one's competence to perform various activities. According to Zamboni et al. (2013), the self-awareness deficit caused by brain damage is also called anosognosia ("disease unawareness") and is characterized by the inability to distinguish one's own neurological or psychiatric disability (e.g., cognitive, physical, behavioural, or emotional). Self-awareness disorders can also be selective. Patients may be aware of some deficits while others do not perceive them (Toglia and Maeir, 2018).

Two perspectives can be seen in the traced definitions of self-awareness: (a) the ability to objectively perceive and assess one's situation in relation to an existing deficit; and (b) the ability to subjectively understand the importance of these problems and their projection into everyday life (Cova et al., 2017; Robertson and Schmitter-Edgecombe, 2015).

Theoretical models of self-awareness help to map its complexity and provide guidance on how best to provide therapy with the individual specialties of the interdisciplinary team. Crosson et al. (1989), in the proposed Pyramid model of self-awareness, describe three hierarchically arranged levels of self-awareness: intellectual (rational), urgent (emergent) and anticipatory (predictive) - Fig. 2. Intellectual self-awareness is the lowest level, but it forms the basis of self-awareness. It includes the ability of a person at a basic level to understand that a function is impaired. This means that one understands that one has a problem in some specific activity (Chesnel et al., 2018). Higher skill in intellectual self-awareness is the ability to distinguish some contexts in activities in which the person has difficulty. Urgent (emergent) self-awareness is the patient's ability to distinguish the existence of a problem that has already occurred during a certain daily activity. It also includes monitoring the problems that arise in connection with the implementation of the activity and selecting an appropriate strategy. Anticipatory self-awareness is the highest level of self-awareness and means the patient's ability to anticipate possible problems in performing activities in the future. The individual can anticipate the problem situation and can plan the use of a certain strategy or compensation that would reduce the risk of the problem.

Intellectual self-awareness must exist before urgent and anticipatory self-awareness. The model intuitively recommends the use of compensatory strategies at all these levels of self-awareness (e.g., education to improve metacognitive or emerging self-awareness or taking notes to improve anticipatory self-awareness for memory problems).

The second theoretical model of self-awareness is based on the above, but the authors do not consider the hierarchical arrangement of individual levels of self-awareness, but rather consider a dynamically interconnected model (Toglia and Kirk, 2000). Both models combine self-awareness, executive function and task or activity (Fig. 3).

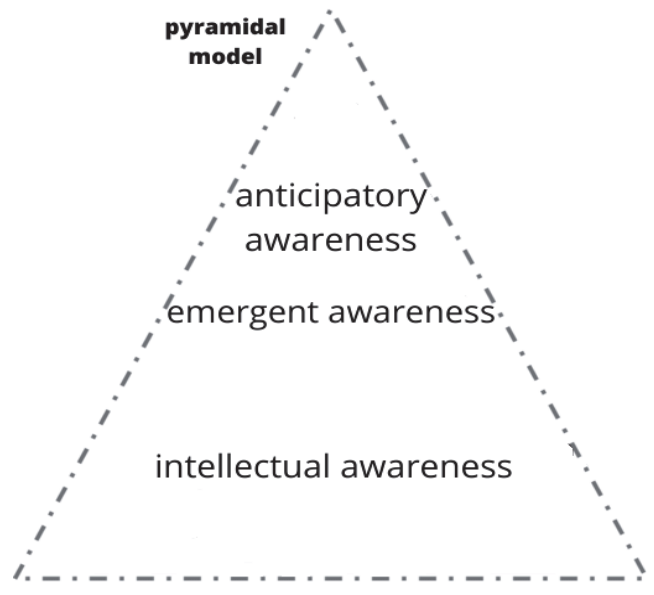

Fig. 2. Pyramidal model of self-awareness (Crosson et al., 1989)

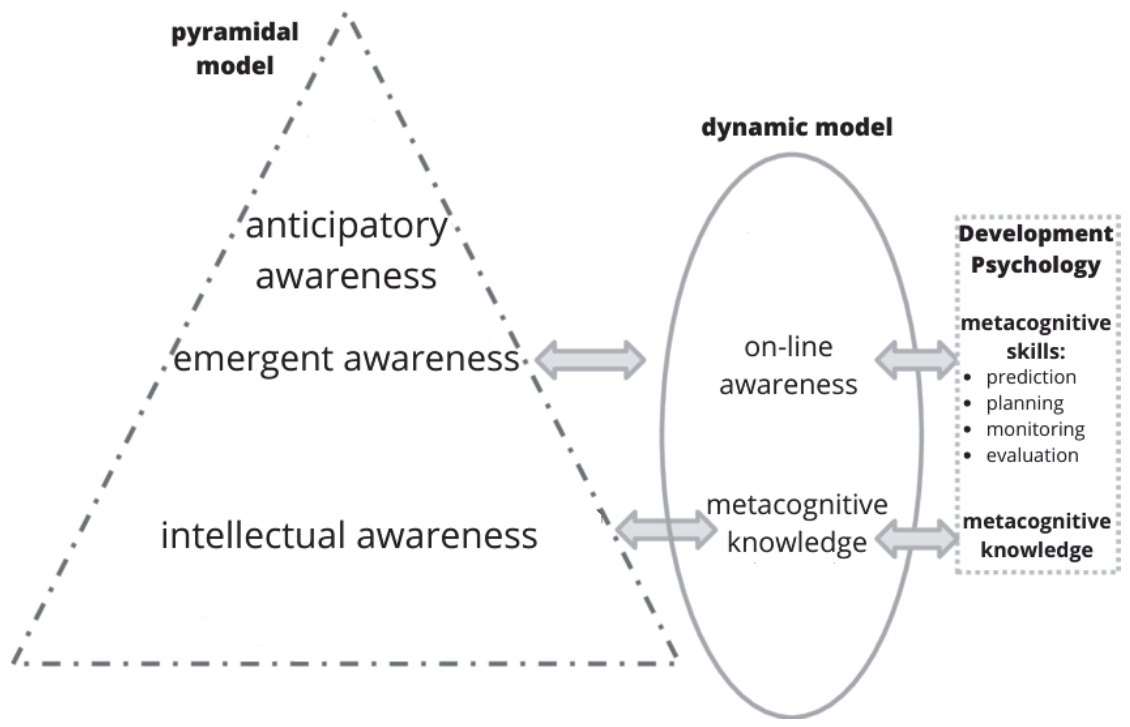

Fig. 3. Dynamic model of self-awareness (Toglia and Kirk, 2000) 


\section{Evaluation of self-awareness}

Problems in the conceptualization of self-awareness, its definitions, and inaccuracies in the methodology of self-awareness research are also reflected in the diversity of methods of its evaluation. In practice, questionnaires, a structured interview, assessment scales, in-service observations or comparisons of a patient's self-assessment and self-awareness by a therapist or family are often used. Several studies recommend evaluating self-awareness before intervention. However, unambiguous recommendations for some evaluations are still lacking (Al Banna et al., 2016; Mahoney et al., 2019; Winkens et al., 2019).

When selecting a suitable tool for self-awareness assessment, it is recommended to use standardized methods that have a well-defined method of administration, evaluation, and verification of whether the tool evaluates a certain attribute (validity) and with what accuracy (reliability). A specific problem of standardization is the translation and transfer of a foreign instrument to our cultural environment and the use of the Czech adaptation of the instrument, which has not been validated for the $C$ zech population. This affects the correct interpretation of the results of the tools (scales, questionnaires, tests), but above all their credibility. Ideally, the translation should be based on knowledge of the concept it measures and consider the specifics of the target cultural environment.

In addition to the psychometric characteristics and length of administration, we also consider the method of assessing the self-awareness disorder. There are two methods of assessing a self-awareness disorder: (a) the therapist's assessment and (b) the difference in the assessment of the patient and a loved one or caregiver (Sherer and Fleming, 2014). The second method of self-awareness assessment is more commonly used in patients with lesions in the frontal lobes, especially in traumatic brain injury (Chesnel et al., 2018; Hart et al., 2009) and in Alzheimer's disease (Zamboni et al., 2013). Although some authors report that the two methods of self-awareness assessment often correlate with each other (Levy et al., 2018), patient self-awareness assessment is often very different (Leicht et al., 2010; McGuire et al., 2014).

Based on the searched literature, 7 self-awareness evaluations were found. The most common evaluations in the studies are: Patient Competency Rating Scale (PCRS), Awareness Questionnaire (AQ), Self-Awareness of Deficits Interview (SADI) and Self-Regulation and Skills Interview (SRSI). The psychometric parameters and the level of self-awareness that the assessment measures are listed in Table 2.

The Patient Competency Rating Scale (PCRS) assesses self-awareness in 30 items in patients after traumatic brain injury (Kolakowsky-Hayner et al., 2012; Prigatano et al., 1986). It includes self-awareness by the patient and family or therapist. Respondents assess the patient's ability in various everyday situations that require the involvement of cognitive, physical, emotional, or behavioural functions. Its administration takes 10 minutes and uses a 5-point scale ( 1 = I am not able to do it, 5 = I can do it without any problems). The total score is in the range of 30-150, where a higher score indicates greater self-awareness of the patient. The scale offers several scoring options: (a) the difference between the patient's and family or therapist's overall score, (b) the assessment of the difference between patient and family or therapist's variations in individual items, and (c) the number of items in which assessments differ. There is a 13-item modified version of the Patient Competency Rating Scale for Neurorehabilitation (PCRS-NR) that is used in hospitalized patients in the acute stage of the disease (Borgaro and Prigatano, 2003).
The Awareness Questionnaire (AQ) is used in adult patients after acquired brain injury. It is a simple 10-minute questionnaire that uses self-awareness assessment by the patient (17 items), family member and therapist (18 items). Self-awareness is assessed on a 5-point scale ( 1 = much worse, $5=$ much better). The total score is in the range of $17-85$. Score 51 means the level of functioning at the same level as before the disease. Self-awareness disorder is determined by comparing differences in the overall score between a patient and a family or therapist (Sherer et al., 2003). Factor analysis identified three assessment factors: cognitive, behavioural, and motor skills (Sherer et al., 1998).

The Self-Awareness of Deficits Interview (SADI) is a 30-minute semi-structured interview conducted by a therapist that assesses the patient's self-awareness in three areas: self-awareness of deficit, the functional effects of reduced self-awareness, and the ability to set realistic goals. It uses a 4-point scale ( 0 = no self-awareness disorder, 3 = severe self-awareness disorder). It is recommended to supplement the evaluation with an interview with the family or therapists. A higher score in each area means a reduced level of self-awareness. A maximum score of 9 means a severe self-awareness disorder. The overall score is greatly influenced by the judgment of the administrator conducting the interview (Fleming et al., 1998).

The Self-Regulation Skills Interview (SRSI) is a semi-structured interview that assesses self-awareness in patients in the subacute to chronic stages of the disease (Ownsworth, 2010). In 6 questions, it evaluates metacognitive and self-regulatory abilities: emergent self-awareness, anticipatory self-awareness, readiness for change, generation of strategies, degree of use of strategies and effectiveness of used strategies. Evaluation is appropriate to use in patients who can have basic (intellectual) levels of self-awareness. The duration of the administration is 40 minutes, and the scoring is on a 10-point scale ( 0 = very high, 10 = very low).

Most of the evaluations evaluate self-awareness by means of an interview or a questionnaire rather than within functional activities. Only the SRSI assessment focuses on self-assessment in everyday activities. Observation of the patient during the activity significantly prolongs the length of administration. SRSI has the longest administration length of all evaluations.

Similarly, most of the evaluations allow for the evaluation of self-awareness from the point of view of family or therapists (PCRS, PCRS-NR, AQ, SADI). Two of them - PCRS and AQ contain a version for patient assessment, family assessment and therapist assessment.

All the most frequently used ratings have very good reliability. Design validity is only found for AQ. Discriminatory or convergent validity is confirmed in further evaluations. It is necessary to further determine the validity of these evaluations, specifically in patients after a stroke or already in the subacute stage of the disease.

Studies evaluating metacognition most used SADI and SRSI (Ownsworth and Fleming, 2005; Ownsworth et al., 2000; 2006; Wise et al., 2005).

It is important for practice to use assessments that consider all levels of self-awareness, as the effect of treatment and discharge planning is significantly related to the patient's level of self-awareness (Mahoney et al., 2019). Only two assessments assess self-awareness at all levels - intellectual, emergent, and anticipatory - SRSI and SADL-3. They provide information not only about the patient's ability to perceive the presence of a problem, but also about the ability to anticipate problems, monitor them and be able to use strategies to eliminate them. 
Table 2. Awareness assessment from the literature search

\begin{tabular}{|c|c|c|c|c|c|}
\hline Assessment & Author & Population & $\begin{array}{l}\text { Reliability } \\
\text { a) test-retest } \\
\text { b) internal } \\
\text { consistency } \\
\text { c) inter-rater }\end{array}$ & Validity & $\begin{array}{l}\text { Level of self- } \\
\text { awarness }\end{array}$ \\
\hline $\begin{array}{l}\text { Patient Competency } \\
\text { Rating Scale (PCRS) }\end{array}$ & $\begin{array}{l}\text { Prigatano et al., } \\
1986\end{array}$ & $\begin{array}{l}\text { Traumatic brain } \\
\text { injury }\end{array}$ & $\begin{array}{l}\text { a) } r=0.85-0.97 \\
\text { b) Cronbach's alpha } \\
0.91-0.95 \\
\text { c) } r=0.82-0.85\end{array}$ & $\begin{array}{l}\text { Convergent validity: } \\
\text { moderately strong correlation with PCRS, } \\
\text { AQ and BI } \\
\text { Discriminant validity: for both versions } \\
\text { (patient, family) } \\
\text { Content validity: good discrimination } \\
\text { between patients with TBI and without } \\
\text { (can also be used in other neurologic } \\
\text { diagnosis) }\end{array}$ & $\begin{array}{l}\text { Intellectual (total } \\
\text { score difference } \\
\text { between patient } \\
\text { and family) }\end{array}$ \\
\hline $\begin{array}{l}\text { Patient Competency } \\
\text { Rating Scale for } \\
\text { Neurorehabilitation } \\
\text { (PCRS-NR) }\end{array}$ & $\begin{array}{l}\text { Borgaro and } \\
\text { Prigatano, } 2003\end{array}$ & $\begin{array}{l}\text { Traumatic brain } \\
\text { injury, acute } \\
\text { state }\end{array}$ & $\begin{array}{l}\text { a) data is missing } \\
\text { b) Cronbach's alpha } \\
0.78-0.87 \\
\text { Total score } 0.82 \\
\text { c) data is missing }\end{array}$ & $\begin{array}{l}\text { Discriminant validity: for both versions } \\
\text { (patient and family) }\end{array}$ & $\begin{array}{l}\text { Intellectual } \\
\text { (total score } \\
\text { difference } \\
\text { between patient } \\
\text { and family) }\end{array}$ \\
\hline $\begin{array}{l}\text { Awareness } \\
\text { Questionnaire (AQ) }\end{array}$ & $\begin{array}{l}\text { Sherer et al., } \\
1998\end{array}$ & $\begin{array}{l}\text { Acquired brain } \\
\text { injury }\end{array}$ & $\begin{array}{l}\text { a) data is missing } \\
\text { b) Cronbach's alpha } \\
0.93 \text { (patient) } \\
0.87 \text { (family) } \\
\text { c) data is missing }\end{array}$ & $\begin{array}{l}\text { Convergent validity: significant correlation } \\
\text { with SADI } \\
\text { Construct validity: } 3 \text { factors (cognitive, } \\
\text { behavioral, motor) } \\
\text { Predictive validity: } \\
\text { Productivity and employment after disease }\end{array}$ & $\begin{array}{l}\text { Intellectual (total } \\
\text { score difference } \\
\text { between patient } \\
\text { and family or } \\
\text { therapist) }\end{array}$ \\
\hline $\begin{array}{l}\text { Self-Awareness of } \\
\text { Deficits Interview } \\
\text { (SADI) }\end{array}$ & $\begin{array}{l}\text { Fleming et al., } \\
1998\end{array}$ & $\begin{array}{l}\text { Traumatic brain } \\
\text { injury, stroke }\end{array}$ & $\begin{array}{l}\text { a) } r=0.85-0.94 \\
\text { b) Cronbach's alpha } \\
0.93 \text { (patient) } \\
0.87 \text { (family) } \\
\text { c) } r=0.82-0.85\end{array}$ & $\begin{array}{l}\text { Convergent validity: significant correlation } \\
\text { with SADI (total score) and AQ (difference } \\
\text { score rating) } \\
\text { Strong relationship with assessment of } \\
\text { executive functions, indirect relationship } \\
\text { with coping strategy assessment }\end{array}$ & $\begin{array}{l}\text { Intellectual } \\
\text { Emergent }\end{array}$ \\
\hline $\begin{array}{l}\text { Self-Regulation } \\
\text { Skills Interview } \\
\text { (SRSI) }\end{array}$ & $\begin{array}{l}\text { Ownsworth } \\
\text { et al., } 2000\end{array}$ & $\begin{array}{l}\text { Acquired brain } \\
\text { injury }\end{array}$ & $\begin{array}{l}\text { a) } r=0.69 \\
\text { (strategy generation) } \\
r=0.91 \\
\text { (anticipatory } \\
\text { awareness) } \\
\text { b) data is missing } \\
\text { c) } r=0.81 \\
\text { (anticipatory } \\
\text { awareness) } \\
r=0.92 \\
\text { (strategy) }\end{array}$ & $\begin{array}{l}\text { Discriminant validity: } \\
\text { Discriminate between TBI and other } \\
\text { acquired brain injury in relation to } \\
\text { awareness assessment and strategy choice. } \\
\text { Does not discriminate in the area of } \\
\text { readiness for change } \\
\text { Convergent validity: strong correlation } \\
\text { with SADI and Health and Safety Scale } \\
\text { Criterion validity: } \\
\text { Significant relationship between SRSI and } \\
\text { neuropsychological assessment }\end{array}$ & $\begin{array}{l}\text { Intellectual } \\
\text { Emergent } \\
\text { Anticipatory }\end{array}$ \\
\hline $\begin{array}{l}\text { Self-Awareness in } \\
\text { Daily Life-3 } \\
\text { (SADL-3) }\end{array}$ & $\begin{array}{l}\text { Winkens et al., } \\
2019\end{array}$ & $\begin{array}{l}\text { Acquired brain } \\
\text { injury }\end{array}$ & $\begin{array}{l}\text { a) } r=0.93 \\
\text { (total score) } \\
\text { b) data is missing } \\
\text { c) } 0.64 \\
\text { (total score) }\end{array}$ & $\begin{array}{l}\text { Convergent validity: moderately strong } \\
\text { correlation with AQ, PCRS and CRS-ISA- } \\
\text { DD }\end{array}$ & $\begin{array}{l}\text { Intellectual } \\
\text { Emergent } \\
\text { Anticipatory }\end{array}$ \\
\hline $\begin{array}{l}\text { Head Injury } \\
\text { Behaviour Scale } \\
\text { (HIBS) }\end{array}$ & $\begin{array}{l}\text { Godfrey et al., } \\
1987\end{array}$ & $\begin{array}{l}\text { Traumatic brain } \\
\text { injury }\end{array}$ & $\begin{array}{l}\text { a) } r=0.68 \\
\text { b) Cronbach's alpha } \\
0.90 \\
\text { (for both versions) } \\
\text { c) } 0.87-0.93\end{array}$ & $\begin{array}{l}\text { Convergent validity: strong correlation } \\
\text { with PCRS and moderately strong } \\
\text { correlation with SADI } \\
\text { Criterion validity: } \\
\text { moderately strong correlation with } \\
\text { Behaviour Assessment Scale and Social } \\
\text { Behaviour Assessment Scale }\end{array}$ & Intellectual \\
\hline
\end{tabular}




\section{Conclusions}

Failure of self-awareness is a common consequence of acquired brain injury. Intact self-awareness is important for the perseverance, motivation, and active effort that any therapy requires. Therefore, promoting self-awareness of patients with acquired brain injury is an important part of the rehabilitation process.

The issue of evaluation of metacognition and self-awareness and their influence on the involvement of patients with acquired brain injury in everyday life is gaining prominence, especially abroad. According to the research, this problem has not yet been comprehensively solved in the Czech environment.

The research also shows that self-awareness is a complex concept that is part of metacognition. Its definition is incon- sistent. Most often, self-awareness is conceptualized as the ability to objectively perceive and assess one's own situation while maintaining a certain subjectivity in understanding its importance to a person. These problems are then reflected in the method of self-awareness assessment. Only two of the sought-after objective self-awareness assessments assess all its levels - the Self-Regulation Skills Interview (SRSI) and the newer Self-Awareness in Daily Life-3 (SADL-3).

When choosing a suitable self-awareness assessment, it is necessary to consider, in addition to the assessment of psychometric parameters and the length of administration, also the verification of the validity of its Czech adaptation.

\section{Conflict of interests}

The authors have no conflict of interests to declare.

\section{Náhled a jeho hodnocení u pacientů po získaném poškození mozku}

\section{Souhrn}

Úvod: Porucha náhledu je komplexní kognitivně behaviorální porucha, která je typická u pacientů po získaném poškození mozku. Deficit náhledu u těchto pacientů způsobuje sníženou motivaci k rehabilitaci nebo nerealistická očekávání. Vede k horším výsledkům $\mathrm{v}$ terapii a k problémům zapojit se do aktivit v širší komunitě a do zaměstnání.

Cíl: Cílem přehledové studie je popsat definice a teoretické modely náhledu a shrnout závěry výzkumů ke způsobu hodnocení náhledu u dospělých pacientů po získaném poškození mozku za posledních 15 let.

Metodika: Rešerše s prvky systematizace za použití metodiky PRISMA. Vyhledávání bylo provedeno v bibliografických a multioborových elektronických databázích (Web of Science, CINAHL, MEDLINE, EBSCO, ScienceDirect, Scopus). Do práce jsou začleněny studie publikované od roku 2005 do roku 2020 včetně.

Výsledky: Celkem bylo vyhledáno 544 zdrojů. Do finální rešerše bylo zařazeno 14 studií, které spadají do jedné ze tří kategorií: definice náhledu, modely náhledu a hodnocení náhledu.

Závěr: Z rešerše vyplývá, že náhled je komplexní pojem, který je součástí metakognice. Jeho definice je nejednotná. Nejčastěji je náhled konceptualizován jako schopnost objektivního vnímání a posouzení vlastní situace při zachování určité subjektivity v porozumění její důležitosti pro člověka. Pouze dva z vyhledaných objektivních hodnocení náhledu hodnotí všechny jeho úrovně.

Klíčová slova: anosognosie; hodnocení náhledu; poruchy náhledu; získaná poškození mozku

\section{References}

1. Al Banna M, Abdulla Redha N, Abdulla F, Nair B, Donnellan C (2016). Metacognitive function poststroke: a review of definition and assessment. J Neurol Neurosurg Psychiatry 87: 161-166. DOI: 10.1136/jnnp-2015-310305.

2. BIAA - Brain Injury Association of America (2017). What is the difference between an acquired brain injury and a traumatic brain injury? [online] [cit. 2020-09-10]. Available from: https:// www.biausa.org/brain-injury/about-brain-injury/nbiic/whatis-the-difference-between-an-acquired-brain-injury-and-atraumatic-brain-injury

3. Bloomfield J, Woods D, Ludingon J (2016). Self-awareness of memory impairment in Parkinson's disease: A review of the literature. Working with Older People 20(1): 57-64. DOI: 10.1108/WWOP-08-2015-0019.

4. Borgaro SR, Prigatano GP (2003). Modification of the Patient Competency Rating Scale for use on an acute neurorehabilitation unit: the PCRS-NR. Brain Inj 17(10): 847-853. DOI: 10.1080/0269905031000089350.

5. Chesnel CC, Jourdan C, Bayen E, Ghout I, Darnoux E, Azerad S, et al. (2018). Self-awareness four years after severe traumatic brain injury: Discordance between the patient's and relative's complaints. Results from the Paris-TBI study. Clin Rehabil 32(5): 692-704. DOI: 10.1177/0269215517734294.
6. Cova I, Grande G, Cucumo V, Ghiretti R, Maggiore L, Galimeberti D, et al. (2017). Self-awareness for memory impairment in amnestic mild cognitive impairment: A longitudinal study. Am J Alzheimers Dis Other Demen 32(7): 401-407. DOI: 10.1177/15333175117725812.

7. Crosson C, Barco PP, Velozo C, Bolesta MM, Cooper PV, Werts D, Brobeck T (1989). Awareness and compensation in postacute head injury rehabilitation. J Head Trauma Rehabil 4: 46-54. DOI: 10.1097/00001199-198909000-00008.

8. Fleming JM, Strong J, Ashton R (1998). Cluster analysis of self-awareness levels in adults with traumatic brain injury and relationship to outcome. J Head Trauma Rehabil 13: 39-51. DOI: 10.1097/00001199-199810000-00006.

9. Godfrey HPD, Marsh NV, Partridge F (1987). Severe traumatic head injury and social functioning: a review. New Zeal J Psychol 16: 49-57.

10. Hart T, Seignourel PJ, Sherer M (2009). A longitudinal study of awareness of deficit after moderate to severe traumatic brain injury. NeuropsycholRehabil 19(2): 161-176. DOI: 10.1080/09602010802188393.

11. Janečková M (2010). Fakta o poranění mozku. In: Powell T (Ed.). Poškození mozku: Praktický průvodce pro terapeuty, rodinné př́islušníky a pacienty. Praha: Portál, p. 21.

12. Klonoff PS (2010) Psychotherapy after brain injury: principles and techniques. New York: The Guilford Press, 288 p. 
13. Kolakowsky-Hayner SA, Wright J, Bellon K (2012). A Brief Overview of the Patient Competency Rating Scale. J Head Trauma Rehabil 27(1): 83-85. DOI: 10.1097/ HTR.0b013e31823645db.

14. Leicht H, Berwig M, Gertz H-J (2010). Anosognosia in Alzheimer's disease: the role of impairment levels in assessment of insight across domains. J Int Neuropsychol Soc 16: 463-473. DOI: $10.1017 /$ S1355617710000056.

15. Levy S, Gansler D, Huey E, Wassermann E, Grafman J (2018). Assessment of Patient Self-awareness and Related Neural Correlates in Frontotemporal Dementia and Corticobasal Syndrome. Arch Clin Neuropsychol 33(5): 519-529. DOI: 10.1093/arclin/acx105.

16. Mahoney D, Gutman SA, Gillen G (2019). A Scoping Review of Self-Awareness Instruments for Acquired Brain Injury. Open J Occup Ther 7(2). DOI: 10.15453/2168-6408.1529.

17. McGuire BE, Morrison TG, Barker LA, Morton N, McBrinn J, Caldwell S, et al. (2014). Impaired self-awareness after traumatic brain injury: inter-rater reliability and factor structure of the Dysexecutive Questionnaire (DEX) in patients, significant others and clinicians. Front Behav Neurosci 8: 352. DOI: 10.3389/fnbeh.2014.00352.

18. Ownsworth T (2010). A metacognitive contextual approach for facilitating return to work following acquired brain injury: three descriptive case studies. Work 36: 381-388. DOI: 10.3233/ WOR-2010-1041.

19. Ownsworth T, Fleming J (2005). The relative importance of metacognitive skills, emotional status, and executive function in psychosocial adjustment following acquired brain injury. J Head Trauma Rehabil 20: 315-332. DOI: 10.1097/00001199200507000-00004.

20. Ownsworth T, Desbois J, Grant E, Fleming J, Strong J (2006). The associations among self-awareness, emotional well-being, and employment outcome following acquired brain injury: a 12-month longitudinal study. Rehabil Psychol 51(1): 50-59. DOI: 10.1037/0090-5550.51.1.50.

21. Ownsworth TL, McFarland K, Young RM (2000). Development and standardization of the Self-Regulation Skills Interview (SRSI): A new clinical assessment tool for acquired brain Indry. Clin Neuropsychol 14(1): 76-92. DOI: 10.1076/13854046(200002)14:1;1-8;FT076.

22. Powell TJ (2010). Poškození mozku: praktický průvodce pro terapeuty, rodinné příslušníky a pacienty. Praha: Portál, 200 p.

23. Prigatano GP, Fordyce D, Zeiner H, Roueche J, Pepping M, Wood B, et al. (1986). Neuropsychological rehabilitation after brain Injury. Baltimore, MD: John Hopkins University Press.

24. Reich E, Arias E, Torres C, Halac E, Carlino M (2015). Anosognosia and self-awareness in multiple sclerosis. J Neurol Sci 357(1): e317. DOI: 10.1016/j.jns.2015.08.1111.

25. Richardson C, McKay A, Ponsford JL (2014). The trajectory of awareness across the first year after traumatic brain injury: The role of biopsychosocial factors. Brain Inj 28: 1711-1720. DOI: 10.3109/02699052.2014.954270.

26. Richardson C, McKay A, Ponsford JL (2015). Factors influencing self-awareness following Traumatic brain Indry. J Head Trauma Rehab 30: E43-E54. DOI: 10.1097/HTR.0000000000000048.
27. Rigon J, Burro R, Guariglia C, Maini M, Marin D, Ciurli P, et al. (2017). Self-awareness rehabilitation after Traumatic Brain Injury: A pilot study to compare two group therapies. Restor Neurol Neurosci 35(1): 115-127. DOI: 10.3233/RNN-150538.

28. Robertson K, Schmitter-Edgecombe M (2015). Self-awareness and traumatic brain Injury outcome. Brain Inj 29(7-8): 848-858. DOI: 10.3109/02699052.2015.1005135.

29. Sherer M, Fleming J (2014). Impaired self-awareness. In: Sherer M, Sander AM (Eds). Clinical handbooks in neuropsychology. Handbook on the neuropsychology of traumatic brain Injury. London: Springer, pp. 233-255.

30. Sherer M, Bergloff P, Levin E, High WM, Oden KE, Nick TG, et al. (1998). Impaired awareness and employment outcome after traumatic brain injury. J Head Trauma Rehabil 13(5): 52-61. DOI: 10.1097/00001199-199810000-00007.

31. Sherer M, Hart T, Nick TG (2003). Measurement of Impaired Self-awareness after Traumatic Brain Injury: A Comparison of the Patient Competency Rating Scale and the Awareness Questionnaire. Brain Inj 17: 25-37. DOI: 10.1080/0269905021000010113.

32. Šplíchal J (2017). Poranění mozku. In: Kulišták P (Ed.). Klinická neuropsychologie v praxi. Praha: Karolinum Press, pp. 422-446.

33. Tiar AMV, Dumas JE (2015). Impact of parental acquired brain injury on children: Review of the literature and conceptual model. Brain Inj 29(9): 1005-1017. DOI: 10.3109/02699052.2014.976272.

34. Toglia JP, Kirk U (2000). Understanding awareness deficits following brain injury. NeuroRehabilitation 15: 57-70.

35. Toglia JP, Maeir A (2018). Self-awareness and metacognition: Impact on occupational performance and outcome across the lifespan. In: Katz N, Toglia JP (Eds). Cognition, occupation and participation across the life span: Neuroscience, neurorehabilitation, and models of intervention in occupational therapy. Bethesda, MD: AOTA Press, pp. 143-163.

36. ÚZIS ČR - Institute of Health Information and Statistics of the Czech Republic (2016). Hospitalizovaní v nemocnicích ČR 2015. [online] [cit. 2020-09-05]. Available from: http://www. uzis.cz/category/tematicke-rady/zdravotnicka-statistika/ hospitalizovani

37. WHO (2013). Global action plan for the prevention and control of NCDs 2013-2020. [online] [cit. 2020-09-07]. Available from: http://www.who.int/nmh/publications/ncd-action-plan/en/

38. Winkens I, Prinsen A, Meijerink A, Van Heugten C, Ponds R (2019). Psychometric evaluation of the Self-Awareness in Daily Life-3 Scale (SADL-3) for the assessment of selfawareness after acquired brain injury. Brain Inj 33(5): 598-609. DOI: 10.1080/02699052.2019.1566969.

39. Wise K, Ownsworth T, Fleming J (2005). Convergent validity of self-awareness measures and their association with employment outcome in adults following acquired brain injury. Brain Inj 19: 765-775. DOI: 10.1080/0269905050019977.

40. Zamboni G, Drazich E, McCulloch E, Fillipini N, Mackay CE, Jenkinson M, et al. (2013). Neuroanatomy of impaired self-awareness in Alzheimer's disease and mild cognitive impairment. Cortex 49: 668-678. DOI: 10.1016/j. cortex.2012.04.011. 